\title{
ARTICLES \\ FIVE GENERATIONS OF RUSSIAN CONSTITUTIONS: RUSSIA AS PART OF THE WESTERN LEGAL HERITAGE
}

WILLIAM BUTLER,

Dickinson Law, Pennsylvania State University (Newville, USA)

https://doi.org/10.21684/2412-2343-2019-6-3-13-21

The paper is devoted to the study of the relationship between the Russian constitutional history and Western legal traditions. The author argues the position according to which the constitutionalism has been a part of Russian legal history for centuries. On one view of Russian legal history, a written constitution remained an aspiration of the Russian people that was only partly realized in 1906. Marxist legal thought contemplated, or predicted, the "withering away of law" after a proletarian Revolution; adopting a constitution seemed counter-intuitive to this projected vector of history. This paper explores in general outline the five generations of the constitutions of Russia (1918, 1925, 1937, 1978, and 1993) and the maturing of a constitutional tradition in Russia which has led from a blueprint for communism to fully-fledged constitutional rule-of-law social State in which the constitution acts as a restraint upon the exercise of State power and performs the role that a constitution routinely performs as part of the western legal heritage. The author concludes the 1993 Russian Constitution is, for the first time, a living document that could be considered as a reaction against the Russian past, the embodiment of Russian experience, and the repository of Russian values and desires for its future.

Keywords: constitutional law; constitutionalism; Russian Constitution; legal history; western legal tradition.

Recommended citation: William Butler, Five Generations of Russian Constitutions: Russia as Part of the Western Legal Heritage, 6(3) BRICS Law Journal 13-21 (2019). 


\section{Table of Contents}

\section{Introduction}

\section{The Importance of Russian Constitutional History: Selected Themes Conclusion}

\section{Introduction}

Constitutionalism has been a part of Russian legal history for centuries. This is so despite the fact that for much of its history, subject to certain exceptions, Russia is widely seen prior to 1917 as an absolute monarchy, notwithstanding attempts from at least the eighteenth century onwards to introduce, if not a constitutional monarchy, at least limitations on the exercise of absolute power by the Tsar. ' Constitutionalism was an issue in Russian domestic policy from the successors of Peter the Great (16721725) onwards, figured in Catherine ll's (1729-1796) proposals for reform embodied in her celebrated Nakaz (1767), ${ }^{2}$ was embodied in various literary works from at least A.N. Radishchev (1749-1802) forward, was central to demands of the Decembrists, is believed to have played a role in the "golden age" and earlier of the Russian legal profession, ${ }^{3}$ and achieved some level of recognition with the adoption of the "Basic Law" of the Russian Empire in $1906^{4}$ (sometimes called a Russian Constitution). This aspiration for constitutionalism carried over into the Russian (RSFSR) constitutions of 1918, 1925, 1937, 1978, and 1993.

On one view of Russian legal history, a written constitution remained an aspiration of the Russian people that was only partly realized in 1906 . Marxist legal thought contemplated, or predicted, the "withering away of law" after a proletarian Revolution; adopting a constitution seemed counter-intuitive to this projected vector of history. But the Bolsheviks and their Menshevik allies, appreciating the

Vladimir A. Tomsinov, The Constitutional-Monarchical Tradition in Russian Political Culture in "The Best in the West": Educator, Jurist, Arbitrator, Liber Amicorum in Honour of Professor William Butler 103 (N.lu. Erpyleva \& M.E. Gashi-Butler (eds.), London: Wildy, Simmonds and Hill Publishing, 2014).

2 The Nakaz of Catherine the Great: Collected Texts (W.E. Butler \& V.A. Tomsinov (eds.), Clark, N.J.: Lawbook Exchange, Ltd., 2010).

3 See Richard S. Wortman, The Development of a Russian Legal Consciousness (Chicago; London: University of Chicago Press, 1976); Gary M. Hamburg, Russia's Path Toward Enlightenment: Faith, Politics, and Reason, 1500-1801 (New Haven \& London: Yale University Press, 2016).

4 Marc Szeftel, The Russian Constitution of April 23, 1906: Political Institutions of the Duma Monarchy (Bruxelles: Les Editions de la Librairie Encyclopedique, 1976).

5 Russia is in the unusual position of having been subject to two constitutions simultaneously: its own, and those of the Union of Soviet Socialist Republics $(1924,1936,1977)$, of which the RSFSR was one of the founding members pursuant to the Treaty of the Union of 30 December 1922. The RSFSR was itself a species of federation, as was the USSR after it was formed. 
force of popular desire for a constitution, accommodated the powerful impetus in this direction. The constitutional drafting commission appointed in April 1918 proceeded slowly until Lenin actually took over chairmanship and quickly produced the document that was ultimately accepted.

One might say that violent revolution is part of the western legal tradition. Harold J. Berman pointed out that

[e]ven the great national revolutions of the past - the Russian Revolution of 1917, the French and American Revolutions of 1789 and 1776, the English Revolution of 1640, the German Reformation of 1517 - eventually made peace with the legal tradition that they or some of their leaders had set out to destroy.

Russia, in other words, was not the first country to take severe exception to the existing constitutional order, nor the last. But Russia was exceptional, at least at the outset, in proposing to replace State and Law with a society in which both would eventually "die out," and their respective "deaths" would come at the hands of those who achieved revolution. In the broadest sense, the five generations of Soviet/Russian constitutions in the course of the past century may be seen as a violent reaction against and a gradual return and restoration of the western legal tradition of which Russia has always been a part. The very ideology which guided the leaders of the Russian Revolution originated in Germany, matured in England, and was imported by Russians from Western Europe. The genesis of the violent reaction against the Imperial Russian legal order was generated in the European legal order.

If the ideology underlying the Russian Revolution was imported, its leaders were initially convinced that the ideology and the constitutional and legal institutions generated by the Revolution could be exported. Partly this was the belief that the Russian Revolution would "spark" a world revolution - which did not happen - but from the late 1950s the Soviet constitutional and legal model, it was believed, might be adapted by third world countries to their needs.

It may be said that to varying degrees all constitutions are based on express ideological principles. That is certainly true of the United States constitutional documents: "all peoples are created equal ..."What differs with respect to the 1918 RSFSR Constitution is not the overwhelming presence of ideological positions based on Marxist-Leninist precepts per se, but the proposition that ultimately the State and its legal system were destined to disappear, with a return to a species of communism that resembled in many key respects the primitive communalism from which human society had progressed since its earliest days. Each Russian

6 Harold J. Berman, Law and Revolution: The Formation of the Western Legal Tradition 5 (Cambridge, Mass.: Harvard University Press, 1983). 
constitution thus represented a statement of goals and objectives - a blueprint for the development of society - and a reflection of the role of the legal system in that process; the first four constitutions ultimately failed in achieving that objective to the satisfaction of the Russian people; the fifth-generation constitution is an entirely different matter and appears to be working satisfactorily.

The RSFSR Constitution of 1918 received a decidedly mixed reception abroad. Some were surprised that a Constitution had been adopted at all in Russia; the classics of Marxism-Leninism said nothing about a constitution being necessary or even desirable in a dictatorship of the proletariat. Some feared that the constitution would become a restraint upon the revolutionary processes unleashed by the October revolution. Some believed the 1918 RSFSR Constitution was purely a propaganda exercise and had little in common with a "real" constitution. Yet others suggested that the draftsmen of the 1918 Constitution had borrowed heavily from Woodrow Wilson's Fourteen Points; they found much in common between those documents. Some emphasized the international (rather than the domestic) importance of the Constitution - the references to principles of self-determination, decolonization, equality of rights between States, the emphasis upon social rather than political rights, among others - and stressed the appeal of these principles to, especially, oppressed peoples elsewhere in the world. Or the contribution of the 1918 RSFSR Constitution in due course to subsequent discussions and codifications of international law and political recommendations adopted by, inter alia, the United Nations General Assembly. It is noteworthy that recent western evaluations sympathetic to the importance of the October Russian revolution to the development of law in the twentieth century say nothing about the role of the succeeding generations of Russian constitutions to this process.

With the conclusion of Treaty of the Union of 30 December 1922 forming the former Soviet Union and the adoption in 1924 of the first Constitution of the USSR, attention abroad moved away from the 1918 RSFSR Constitution. Most western scholars ignored the 1918 Constitution; few regarded it as a document having normative force.

The 1924 USSR Constitution was not well-known outside the Soviet Union, and the text of the 1922 Treaty of the Union even less so. Both served as the basis of the RSFSR Constitution of 11 May 1925, which although more detailed than the 1918 text, was regarded as essentially a repetition of the 1922 Treaty and the 1924 USSR Constitution. This text was treated as a proper Constitution but accorded relatively little attention in foreign scholarly writings. With the creation of the USSR, doctrinal writings focused almost exclusively on the USSR constitutional documents and barely mentioned the RSFSR materials.

See, e.g., John B. Quigley, Jr., Soviet Legal Innovation and the Law of the Western World (New York: Cambridge University Press, 2007). 
The 1925 RSFSR, 1937 RSFSR, and 1978 RSFSR constitutions were regarded by western scholars as virtually verbatim clones of the 1924, 1936, and 1977 USSR constitutions respectively, as were all the other union and autonomous republic constitutions. Only the present writer produced English translations of all the 1978 constitutions of the union and autonomous republics. ${ }^{8}$

To express the position in another way, the 1924 USSR Constitution, but more especially the 1936 and 1977 USSR constitutions, were perceived in the West to be quasi-ideological documents and not "real" constitutions intended to restrain abuse of power on the part of parliaments, chief executives, governments, or the judiciary. The 1936 USSR Constitution in particular at the time was introduced to mark the transition of Russia and its sister union republics to the stage of societal development called "socialism," in contrast to the dictatorship of the proletariat which had prevailed previously. To be sure, this transition had immense practical and legal implications, but the 1936 USSR Constitution (and 1937 union republic constitutions) was serving as a record of this transition rather than the progenitor of that transition.

This meant that in Western eyes the Soviet Union, including the Russian Federation, had many formal trappings of constitutionalism (written constitution, parliamentary supremacy, separation of powers, collective chief executive (presidium), government, judiciary, procuracy, and so on), but counter-balanced these with others distinctive to Russia (Russian style of federalism, no checks and balances, democratic centralism, leading role of the Communist Party, nomenklatura, no judicial review of the constitutionality of legislation, supervisory powers of procuracy, and others). These were in most cases perceived abroad to detract from constitutionalism, or indeed even to be anti-constitutionalist.

The transition to the last generation of Soviet constitutions was an extended one, lasting from the early 1960s to 1977. In Western eyes, the 1977 USSR Constitution was notable for progress on human rights (the Soviet Union had ratified the 1966 human rights covenants in 1976) and for its detailed provisions generally. Indeed, with respect to the level of detail, the 1977 USSR Constitution was seen in the West as a trend noted earlier in Central European constitutions - also lengthy detailed texts. This generation of constitutions too marked a transition to a higher level of societal development - a socialist society building communism. In our view, this generation of constitutions introduced higher levels of centralization and federalism, more attention to socialist legality and due process, with the roles of State Arbitrazh and the legal profession being elevated, efforts to strengthen the judiciary, new approaches to ownership, among others. But as in earlier years Western analysts were more impressed by what they perceived as ideological changes and developments than by changes intended to strengthen the role of law.

8 See William E. Butler, Collected Legislation of the USSR and Constituent Union Republics (Dobbs Ferry, N.Y.: Oceana Publications, Inc., 1979). 
During the perestroika years, many of the reforms achieved took place in or were reflected in constitutional change. This means the changes, additions, and amendments to the 1978 RSFSR Constitution between 1988 and 1993 are of great importance. Many of them were incorporated in the 1993 Constitution of the Russian Federation. These changes, and the discussions which accompanied them, finally alerted Western observers to the importance of the Russian Constitution as such and not merely as a reflection of ideological reform.

This would suggest, in turn, that the 1993 Russian Constitution is truly the first "real" constitution in Russian history.

\section{The Importance of Russian Constitutional History: Selected Themes}

The distinctive features of Russian constitutionalism - originating in an absolute monarchy, first appearing in a State dedicated to witnessing the dying out of State and law, serving and underpinning a legal order in which the Constitution was not intended to restrain social progress or State actions - should not obscure the fact that Russian constitutionalism has raised important issues that transcend Russia itself and should engage the attention of those who investigate the impact of revolutions upon the course of legal history. We turn to some of these.

(1) Revolutionary law and legal vacuums. Revolutions are in part a violent reaction against the pre-existing legal order. The Bolsheviks were committed not merely in the long-term perspective to the dying out of State and law, but in the short-term perspective to a complete separation from Imperial law and legal institutions. History demonstrates that a "complete separation" is never realistic or even possible. The notion that a revolutionary movement can, on one hand, repeal all pre-existing legislation and abolish all pre-existing legal institutions without providing suitable replacements has been demonstrated by Russian revolutionary experience to be completely unrealistic and impossible. This may at least partly explain why the 1918 RSFSR Constitution took the form of primarily an ideological document with minimal normative provisions.

The term "revolution" is not used in connection with the dissolution of the Soviet Union on or about 25 December 1991, but arguably what transpired under perestroika might be characterized as a revolution, albeit one that occurred over several years. The outcome was a restructuring of the constitutional system, the introduction of changes and additions to the 1978 RSFSR Constitution that fundamentally altered the political configuration of the Russian Federation, and ultimately led to the 1993 Russian Constitution, which consolidated and advanced those reforms.

Nonetheless, the spectre of a legal vacuum remained, and it was addressed in Russia and the other post-Soviet republics by retaining Soviet legislation unless it had been superseded by Russian legislation, expressly repealed, or was otherwise inconsistent with the values and normative acts of the new regime; 
(2) Reintegration into existing legal families. In my view Russia has been throughout its entire legal history been an integral part of the Western legal heritage. Nothing was done in the Soviet period which would alter that perception. Whether during the Soviet era Russia continued to be part of the Romano-Germanic family of legal systems is another question entirely. In my view not, which simply suggests that within the Western legal tradition a new family of legal systems - socialist legal systems (now transitional legal systems) - was formed. It remains to be seen whether the transitional family of legal systems will lose, maintain, or add features which distinguish them from the Romano-Germanic family.

The Russian constitutions were and are an integral part of such an analysis. It is more in the field of public law, rather than private law, that socialist and transitional legal systems differed from the Romano-Germanic and Common Law families. This was an approach that traditional western comparative legal studies found difficult to accommodate; for them, private law was the domain within which one determined the affiliation of one country to a family of legal systems. They were unaccustomed to analyze public law materials, considering them to be more "political" than "legal" documents. One western analytical study of socialist constitutions which emphasized their importance for distinguishing the socialist legal tradition ${ }^{9}$ was criticized for diminishing the significance of the traditional realm of private law; such an approach would require one to "abandon the philosophical pattern of two and one-half millennia and the comparative concern of a thousand years" ${ }^{10}$

(3) Constitutions and the socialist planned economy. For the moment, the Russian experiment with the socialist planned economy and its legal infrastructure is regarded as a failure, without a thorough diagnosis of why the experiment did not succeed. The second, third, and fourth Russian constitutions served as the infrastructure of this experiment. They were designed not to interfere with the planned economy, at a minimum, and to provide the necessary conceptual and institutional support for the planned economy, at a maximum.

Despite the ultimate outcome and fate of the socialist planned economy, no one should doubt the tremendous influence that experiment had upon other countries and their legal systems. Although western countries did not adopt central economic planning on the scale of Russia, they did introduce aspects of planning, especially in the form of national income accounting, balances of payments, five-year economic plans for targeted development, among others.

The interface between Plan and Law was always a difficult and sensitive balance in Soviet law and the residue of that relationship remains awkward in a legal system

9 John N. Hazard, Communists and Their Law (Chicago: University of Chicago Press, 1969).

10 See Albert A. Ehrenzweig's review of Hazard, supra note 9, in 58 California Law Review 1005, 1007 (1971); noted in William E. Butler, Russian Law and Legal Institutions 1-2 (2 ${ }^{\text {nd }}$ ed., London: Wildy, Simmonds and Hill Publishing, 2018). 
in transition to a market economy. Soviet law never found the proper formula to balance administrative command with the law of contract; it may well be that there is no proper formula. The civil law reforms of the past six years in Russia - which have done much to strengthen the transition to a market economy - have mostly been ignored abroad. These have not occurred in the form of constitutional change - they did not require constitutional amendments because the 1993 Constitution is already well-suited to their introduction. They have occurred at the level of changes in the Civil Code and in judicial practice - all within the constitutional framework;

(4) Enhancement of the Russian legal profession. It was always something of a puzzle as to why the Advokatura continued to exist throughout the Soviet period. Initially, the Soviet authorities reacted with suspicion and hostility to the advokat as a survival of the bourgeois past, but never took the step of abolishing the Advokatura or - as happened in China - assimilating the Advokatura to State employees. This in itself, in my view, was an indication that Soviet Russia remained within the western legal heritage. In due course the "right to defense" was given constitutional stature in Soviet constitutions and strengthened in the 1993 Constitution.

Any Advokatura is inherently a form of restraint upon the exercise of State power - an institution dedicated to resisting State abuses in enforcing its own laws and ensuring the proper representation of parties to other cases in courts and private arbitration. Even within the Planned Economy this constructive role for the Advokatura was recognized, legal education was expanded, the jurisconsult became an integral part of the administrative and economic system, and the role of law and legal institutions was enhanced. Rightly or wrongly, the development of the Russian and Soviet legal professions is seen not only as evidence of Imperial Russia, Soviet Russia, and modern Russia being an integral component of the western legal heritage, but as making a substantial contribution to Russian constitutionalism.

\section{Conclusion}

Real constitutionalism cannot be meaningful without a commitment to the rule of law, and a commitment to the rule of law means a commitment to the profession whose primary task is to uphold the law against the State, on behalf of the State, in relations between juridical persons and citizens.

The 1993 Constitution of the Russian Federation is doing precisely that. It is the first real Constitution in Russian history precisely because it is performing those functions. That Constitution, of course, will mature through application by the courts and by all concerned, and from time to time it may be considered desirable to make changes and additions. In this sense the 1993 Russian Constitution is a reaction against the Russian past, the embodiment of Russian experience, and the repository of Russian values and desires for its future. It is, for the first time, a living document rather than a mere restatement of programmatic provisions. 


\section{References}

Berman H.J. Law and Revolution: The Formation of the Western Legal Tradition (Cambridge, Mass.: Harvard University Press, 1983).

Butler W.E. Collected Legislation of the USSR and Constituent Union Republics (Dobbs Ferry, N.Y.: Oceana Publications, Inc., 1979).

Hamburg G.M. Russia's Path Toward Enlightenment: Faith, Politics, and Reason, 1500 1801 (New Haven \& London: Yale University Press, 2016). https://doi.org/10.12987/ yale/9780300113136.001.0001

Hazard J.N. Communists and Their Law (Chicago: University of Chicago Press, 1969).

Quigley J.B., Jr. Soviet Legal Innovation and the Law of the Western World (New York: Cambridge University Press, 2007). https://doi.org/10.1017/cbo9780511511219

Szeftel M. The Russian Constitution of April 23, 1906: Political Institutions of the Duma Monarchy (Bruxelles: Les Editions de la Librairie Encyclopedique, 1976).

The Nakaz of Catherine the Great: Collected Texts (W.E. Butler \& V.A. Tomsinov (eds.), Clark, N.J.: Lawbook Exchange, Ltd., 2010).

Tomsinov V.A. The Constitutional-Monarchical Tradition in Russian Political Culture in "The Best in the West": Educator, Jurist, Arbitrator, Liber Amicorum in Honour of Professor William Butler 103 (N.lu. Erpyleva \& M.E. Gashi-Butler (eds.), London: Wildy, Simmonds and Hill Publishing, 2014).

Wortman R.S. The Development of a Russian Legal Consciousness (Chicago; London: University of Chicago Press, 1976). https://doi.org/10.7208/chicago/9780226907772. 001.0001

\section{Information about the author}

William Butler (Newville, USA) - John Edward Fowler Distinguished Professor of Law, Dickinson Law, Pennsylvania State University (155 Mt. Rock Road, Newville, Pennsylvania, 17241, USA; e-mail: web15@dsl.psu.edu). 